Спицина С. С. ${ }^{1,2}$, Гончаренко О. В. ${ }^{2}$

\title{
СТРУКТУРНО-ФУНКЦИОНАЛЬНЫЕ ИЗМЕНЕНИЯ СЕРДЦА НА ЭХОКАРДИОГРАФИИ ПРИ РЕВМАТОИДНОМ АРТРИТЕ
}

\author{
(Научный руководитель - д.м.н. Шилова Л. Н.) \\ ${ }^{1}$ Научно-исследовательский институт клинической и экспериментальной ревматологии имени \\ А. Б. Зборовского, \\ ${ }^{2}$ Волгоградский государственный медицинский университет \\ Волгоград, Российская Федерация
}

Введение. Ревматоидный артрит (РА) является наиболее распространенным хроническим системным воспалительным заболеванием опорно-двигательного аппарата, которым страдают в России более 300 тыс. человек (Насонов Е.Л., 2018г.). Поражение сердечно-сосудистой системы - одно из значимых внесуставных проявлений, влияющих на качество жизни и смертность. Кардиоваскулярная патология развивается при РА значительно раньше, чем в общей популяции, что объясняется системным воспалением.

Цель исследования. Оценить эхокардиографические изменения, структурно-функциональные показатели сердца у пациентов с РА.

Материалы и методы. В исследование были включены 15 больных РА с продолжительностью основного заболевания не менее 12 месяцев, без сопутствующей кардиальной патологии, которая могла бы повлиять на изменения сердечно-сосудистой системы, и 20 больных ишемической болезнью сердца (ИБС), которые составили контрольную группу. Обе группы были сопоставимы как по возрасту, так и по длительности заболевания. Всем пациентам была выполнена эхокардиография (Philips iU22).

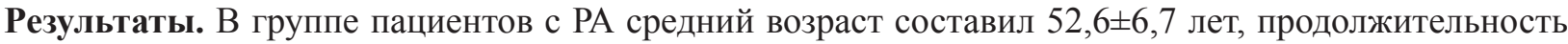
заболевания - от 1,5 до 12 лет, серопозитивность - 60,0\%, АЦЦП-позитивность - 46,7\%, умеренная или высокая активность заболевания (DAS28-CRP(4) $=5,1 \pm 1,6)$. Все больные РА получали базисную противовоспалительную терапию, нестероидные противовопалительные препараты, 33,3\% - глюко-

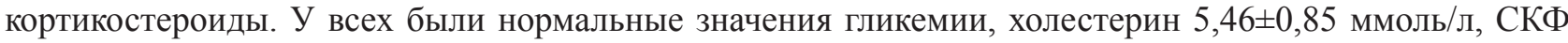
(по CKD-EPI) $>60$ мл/мин/1.73 м². Признаки атеросклеротического поражения аорты были выявлены у $73,3 \%$ больных РА и у 90,0\% больных ИБС, изменения аортального и митрального клапанов - у 46,7\% больных РА и 65,0\% больных ИБС ( $>>0,001)$; признаки кардиосклероза - у 53,3\% больных РА и 70,0\% больных ИБС ( $>>0,001)$; гипертрофия левого желудочка (ЛЖ) - у 40,0\% больных РА и $80,0 \%$ больных ИБС ( $<0,001)$; нарушение диастолической функции ЛЖ - у 53,3\% больных РА и 80,0\% больных ИБС ( $>>0,001)$; снижение сократительной функции ЛЖ только у больных ИБС $(60,0 \%, \mathrm{p}<0,001)$; наличие небольшого количества выпота в перикарде и признаки незначительной легочной гипертензии только у больных РА ( $13,3 \%$ и $6,7 \%$ соответственно, $\mathrm{p}<0,001)$. По данным эхокардиографии все обследованные с РА имели сохраненную систолическую функцию ЛЖ (фракция выброса $>60 \%$ ).

Выводы. В группе больных РА не было выявлено достоверных различий с группой больных ИБС по частоте встречаемости атеросклероза аорты, поражения аортального и митрального клапанов. Гипертрофия ЛЖ и нарушение локальной сократительной способности миокарда при ИБС встречались достоверно чаще, что объясняется основными факторами развития и патофизиологическими механизмами этой патологии. Все пациенты с РА имели сохраненную систолическую функцию ЛЖ. Вместе с тем, незначительные признаки перикардита и легочной гипертензии выявлялись только у больных РА, свидетельствуя о наличии специфического для данного заболевания системного воспалительного процесса. 